\title{
Genetic diversity in Azima tetracantha (Lam) assessed through RAPD analysis
}

\author{
B. Thendral Hepsibha ${ }^{1}$, V. Premalakshmi ${ }^{2}$ and T. Sekar ${ }^{3}$ \\ ${ }^{1}$ Dept. of Biotechnology, Alpha Arts \& Science College, Chennai- 600 116, India \\ ${ }^{2}$ Dept. of Biotechnology, Mother Teresa Women's University, Kodaikanal - 624 102, India \\ ${ }^{3}$ Dept. of Botany, Pachiayappa's College, Chennai - 600 030, India \\ thendraljoel@yahoo.com
}

\begin{abstract}
Azima tetracantha is a shrub known for its various therapeutic properties. Genetic diversity was analysed using RAPD primers among six accessions collected from different locations of Tamilnadu, India. Genetic distances were calculated using Nei's coefficient. Dendrogram was constructed on the basis of the similarity matrix data by unweighted pair group method with average (UPGMA) cluster analysis. The analysis with RAPD markers revealed wide variation within $A$. tetracantha that reflected a high level of diversity within this species.
\end{abstract}

Keywords: Azima tetracantha, genetic diversity, RAPD.

Introduction

Azima tetracantha known as 'Mulchangan' in Siddha is a rambling spinous shrub belonging to the family Salvadoraceae. The presence of quadrangular spines at the nodes is considered to be a unique character (Kirtikar $\&$ Basu, 1984) of this species. The shrub grows widely in most parts of south India, Ceylon, Philippines and in Burma. The ethno botanical survey reveals the usage of this plant for various ailments (Jaswanth et al., 2001; Hebbar et al., 2004; Mohamed et al., 2007; Ignacimuthu et al., 2008). It has been reported for its antimicrobial (Mohamed et al., 2007), analgesic (Nandgude et al., 2007), anti inflammatory (Ismail et al., 1997) and wound healing activity (Jaswanth et al., 2001). The roots and leaves were used as stimulant and tonic.

Botanical additives and their natural compounds have therapeutic effects and have become popular among many consumers (Xie et al., 2005; Xu et al., 2005). However, herbal medicine safety is an important issue that both the government and the researcher must address (Chrubasik et al., 2005; Yoo et al., 2005). Plant wealth is greatly exploited for its therapeutic potential and medicinal efficacy to cure various ailments since time immemorial. For this reason, they were identified and defined by taxonomist at the very early ages of human history, although the taxonomic studies about the genus are limited and especially morphological characters were used in the genus key which can be influenced by environmental conditions (Sumer Aras et al., 2003). In the evolutionary history of a species, the distribution of populations could be constricted or expanded due to the environmental changes (Jin-Ming et al., 2008). Molecular markers could reflect the difference between species directly without affecting the environment (Wang et al., 1996). Several molecular markers particularly the Random Amplified Polymorphic DNA (RAPD), Restriction fragment length polymorphism (RFLP) and Variable Number of Tandem Repeats (VNTR) have been proven useful in detecting genetic diversity. RAPD technique has several advantages such as speed, low cost and the usage of small amounts of plant materials (Jain et al., 1994; Heun et al., 1994; Becerra Velasques \& Gepts, 1994). So far analysis of genetic diversity in $A$. tetracantha has not been carried out. The aim of the present study was to analyse the genetic diversity as well as their relationship in the diminishing wild populations of $A$. tetracantha using the RAPD markers.

\section{Materials and methods Plant materials}

A total of six accessions (Table 1) of Azima tetracantha were collected from various locations in Tamilnadu, India. Young leaves were harvested and placed in sealable plastic bag with appropriate label. The collected leaves were used immediately for DNA extraction, while excess leaf materials were stored in $80^{\circ} \mathrm{C}$ for future use.

DNA extraction

Total genomic DNA was extracted from leaves using a modified CTAB method based on the protocol of Doyle \& Doyle (1990). Quality and concentration of total DNA was verified by UV Spectrophotometry at $260 \mathrm{~nm}$ and 280 $\mathrm{nm}$. Further quality of DNA was tested by submerged horizontal agarose gel $(0.8 \%)$ electrophoresis and visualized under UV light, gel documentation system.

\section{RAPD analysis}

Out of 19, Random decamer primers (Operon technologies, USA) of OPA, OPB \& OPN series were used individually as primers for RAPD analysis. The PCR amplification was carried out in MJ Research, Inc. PTC150 minicycler. PCR reactions were performed in reaction mixture with a total volume of $25 \mu \mathrm{l}$ containing different
Research article

(CIndian Society for Education and Environment (iSee)
"Azima tetracantha: RAPD analysis" http://www.indjst.org
Thendral Hepsibha et al. Indian J.Sci.Technol. 
combinations [DNA con. $(25 \mathrm{ng}$ $\& 50 \mathrm{ng})$, primer conc. $(0.2,0.25$ $\& \quad 0.3 \mu \mathrm{M})$ and Taq DNA polymerase conc. $(0.6,0.8,1.0$ \& $2.0 \mathrm{U}$ ) were tried to optimize the PCR condition. PCR amplification was carried out with pre-denaturation at $94^{\circ} \mathrm{C}$ for $3 \mathrm{~min}$, denaturation at $94^{\circ} \mathrm{C}$
Table 1. Plants collected from the various districts of Tamilnadu

\begin{tabular}{|l|l|}
\hline Population ID & \multicolumn{1}{c|}{ Area of the study / District } \\
\hline Loc1 & Red Hills, Chennai, Thiruvallur Dt. \\
\hline Loc2 & Periyapalayam, Chennai, Thiruvallur Dt. \\
\hline Loc3 & Karisangal , Chennai, Chengalpattu Dt. \\
\hline Loc4 & Kallagam , Trichy Dt. \\
\hline Loc5 & Sirumalai Hills, Dindugal Dt. \\
\hline Loc6 & Sukkambar , Tanjore Dt. \\
\hline
\end{tabular}

dendrogram was constructed (Fig.1) on the basis of the similarity matrix data by un weighted pair group method with average (UPGMA) cluster analysis.

\section{Results and discussion}

The RAPD technique had for $1 \mathrm{~min}$, primer annealing at $36^{\circ} \mathrm{C}$ for $1 \mathrm{~min}$ and primer extension at $72^{\circ} \mathrm{C}$ for 2 min followed by 40 cycles of amplification and final extension at $72^{\circ} \mathrm{C}$ for $7 \mathrm{~min}$. PCR products were kept at $4^{\circ} \mathrm{C}$. Gel electrophoresis was carried out on the amplified products using $2 \%$ agarose, stained with ethidium bromide and visualized under UV illumination. The $1 \mathrm{~kb}$ DNA ladder was used as a molecular weight marker and the amplifications were repeated twice to confirm the results.

Table 2. RAPD primers data and the percentage of polymorphic bands

\begin{tabular}{|c|c|c|c|c|c|}
\hline $\begin{array}{c}\text { Primer } \\
\text { Code }\end{array}$ & $\begin{array}{c}\text { Nucleotide } \\
\text { Sequence }\end{array}$ & $\begin{array}{c}\text { Size of } \\
\text { fragments(bp) }\end{array}$ & $\begin{array}{c}\text { Polymorphic } \\
\text { bands }\end{array}$ & $\begin{array}{c}\text { Monomorphism } \\
\%\end{array}$ & $\begin{array}{c}\text { Polymorphism } \\
\%\end{array}$ \\
\hline OPA7 & GAAACGGGTG & $250-2000$ & 5 & 16.66 & 83.33 \\
\hline OPA10 & GTGATCGCAG & $500-1000$ & 4 & - & 100 \\
\hline OPA18 & AGGTGACCGT & $400-1500$ & 7 & - & 100 \\
\hline OPN9 & TGCCGGCTTG & $500-1500$ & 4 & 20 & 80 \\
\hline OPN6 & GAGACGCACA & $100-2500$ & 7 & - & 100 \\
\hline
\end{tabular}

\section{Data analysis}

Evaluation of fragment patterns was carried out by similarity index. Reproducible bands were scored manually as ' 1 ' or ' 0 ' for presence or absence of the bands. The data was used for similarity - based analysis using the software program NTSYS (2.20). RAPD analyses were analyzed using the Nei genetic similarity index (Nei and Li, 1979). On the basis of the equation, $\mathrm{SI}=2 \mathrm{Nij} /(\mathrm{Ni}+\mathrm{Nj})$

Where $\mathrm{Nij}$ is the number of common bands shared between samples $\mathrm{i}$ and $\mathrm{j}, \mathrm{Ni}$ and $\mathrm{Nj}$ are the total number of DNA bands for genotypes $\mathrm{i}$ and $\mathrm{j}$, respectively. $\mathrm{A}$

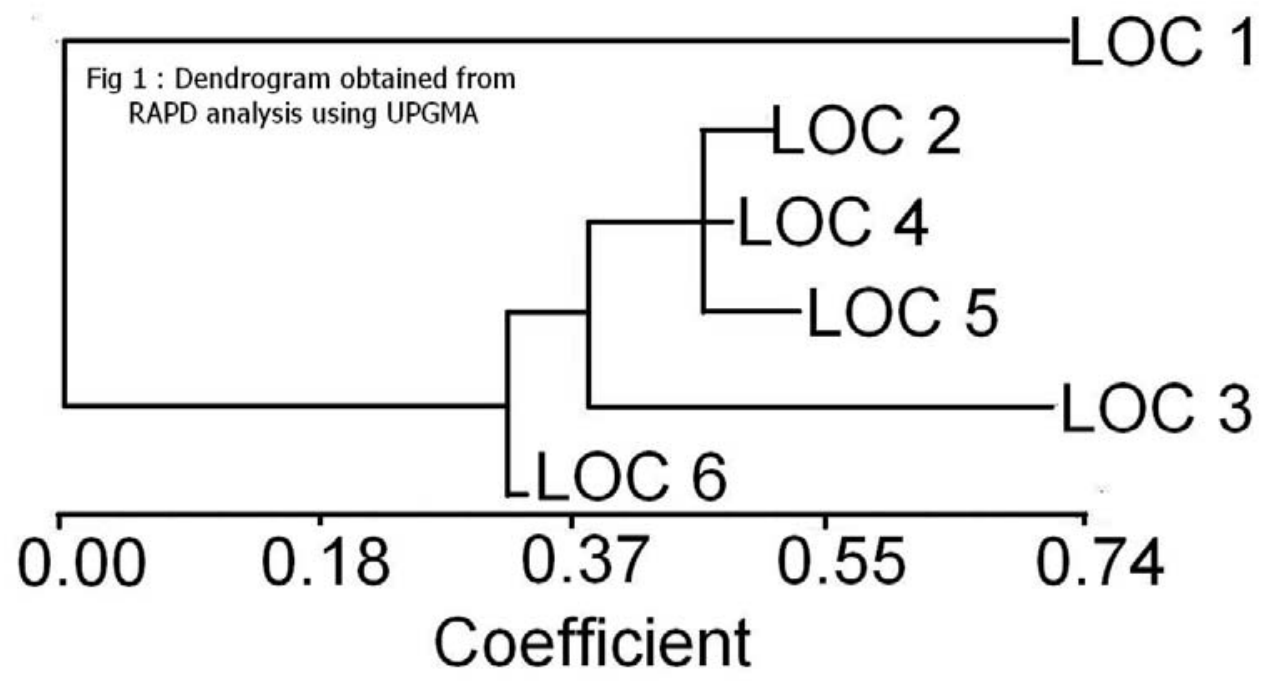

Research article

CIndian Society for Education and Environment (iSee)

"Azima tetracantha: RAPD analysis" http://www.indjst.org ones are present in at least one individual not in any other (Mehetre et al., 2004). The mean percentage of polymorphic bands was $92.66 \%$ with molecular sizes ranged from 0.100 to $2.5 \mathrm{~Kb}$. Only 2 bands of the 29 bands were commonly detected in all the samples which reflected certain homology of the sample. The lesser similarity value of 0.085 indicates high diversity between Loc 1 and Loc 6 species (Table 3). The genetic similarity index between Loc 2 and Loc 4 was highest with a value of 0.900 .

A dendrogram was constructed using neighbor joining method of cluster analysis separated all the six accessions into two clusters at 0.09 similarity coefficient. Cluster 1 has only Loc 1 accession. Cluster 2 contained the remaining five accessions separated into 3 sub clusters. Loc 2, 4, 5 are in a clad. Loc 3 and Loc 6 are in a separate clad (Fig 1).

The genetic structure of plant populations reflects the interactions of many different processes such as the long-term evolutionary history of the species (e.g., shifts in distribution, habitat fragmentation, and/or population isolation), mutation, genetic drift, mating system, gene flow, and selection (Slatkin, 1987; Schaal Indian J.Sci.Technol. 
et al., 1998). All of these factors can lead to complex genetic structuring within populations. Genetic diversity is of great importance to the sustainability of plant populations (Wang et al., 2007). Based on the above collected from an area surrounded by industries and posed to environmental pollution and the resulting genetic adaptation. In the conservation management of a species, knowledge of interspecies genetic variations
Fig 2. Polymorphic band generated by different RAPD primers OPA7

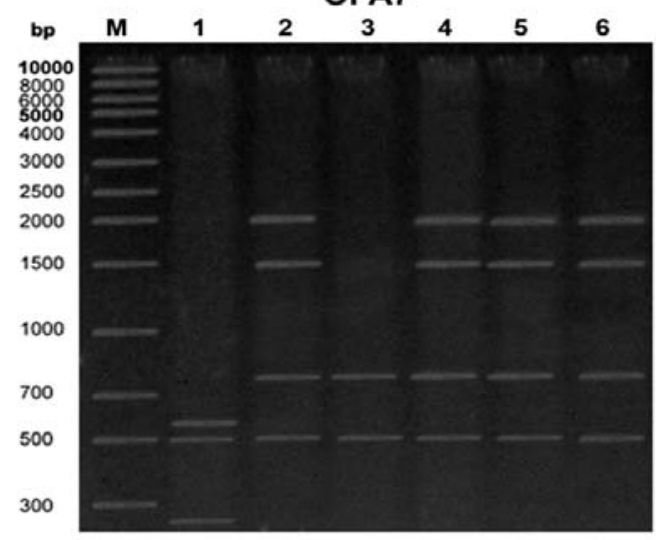

OPA10

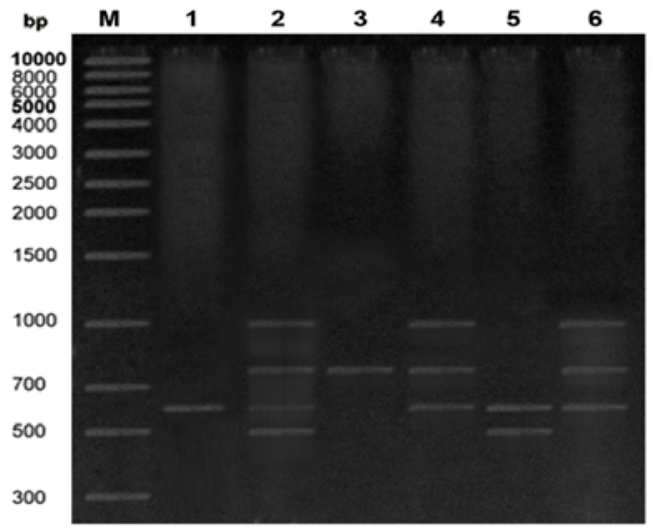

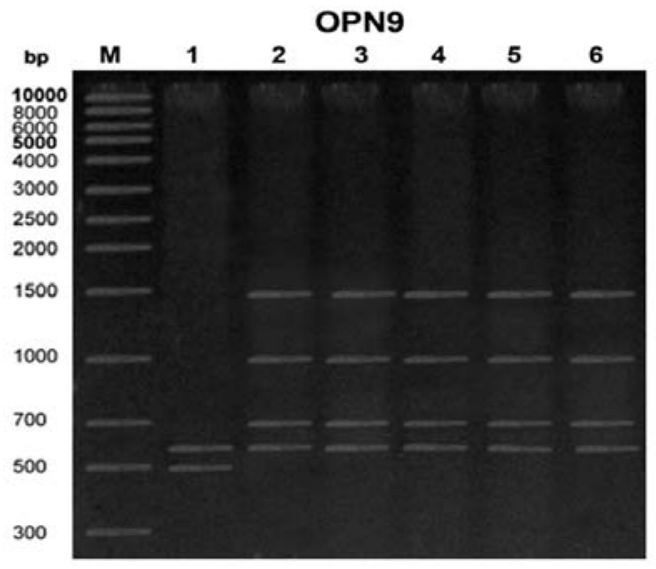

OPA18

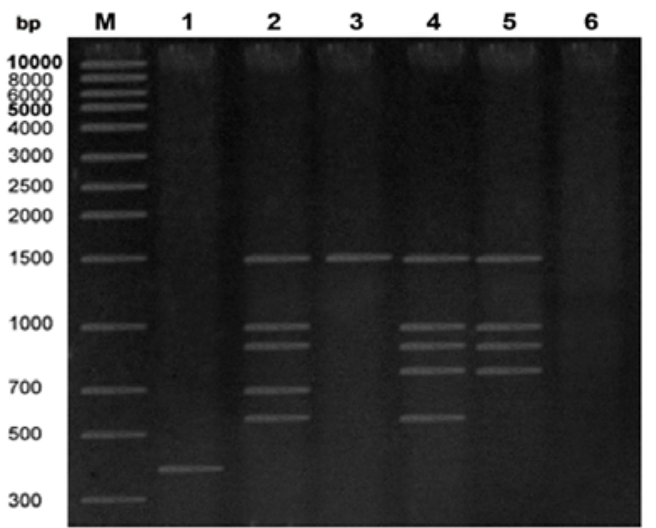
may help to assess extinction risks such as inbreeding and evolutionary potential in a changing world (Hedrick, 2001). Effective conservation of a vulnerable species depends largely on the knowledge of patters of genetic variation. For example, the spatial structure of genetic variation can provide information for sampling strategies for ex situ or in situ conservation (Torre et al., 2008). The herbs type of plant group may provide the best model systems for future studies aimed at illuminating the role of the Quaternary climatic changes in driving diversification and speciation. Short-lived herbs, as opposed to long-lived trees, experience a higher number of life cycles within a given time period, and may have

results there are collections with high similarity index, even though they may be belonging to geographically different locations. High similarity indices suggest that the individuals in the population have close genetic relation among them. This situation can rise in natural populations when there is a possibility of free/random pollen flow and fertilization. The genetic similarity of the samples slightly correlated with their close geographic locations (Sayed et al., 2009).

Sources of polymorphism in RAPD assay may be due to deletion, addition or substitution of base within the priming site sequence (Willams et al., 1990). High diversity is the reflection of adaptation to environment, which is beneficial to its propagation, resources conservation, the domestication of wild species and the screen of specified locus. The accessions collected from Loc 2, Loc 4, Loc 5, Loc 3 and Loc 6 are from different geographical location, but free of pollution. Geographically isolated individuals tend to accumulate genetic variations during the course of environmental adaptations (Sarwat, 2008). Accession from Loc 1 is

Research article

CIndian Society for Education and Environment (iSee)
"Azima tetracantha: RAPD analysis" http://www.indjst.org
Thendral Hepsibha et al. Indian J.Sci.Technol. responded more quickly to environmental change on Quaternary time-scales (Comes \& Kadereit, 1998). This study was an attempt to establish the genetic diversity background in $A$. tetracantha with RAPD markers. High levels of polymorphism found in the present work showed that RAPD markers as a suitable tool for genetic diversity studies. This study could pave the way for detailed research to understand all the aspects of this divergence.

Table 3. Genetic similarity index from RAPD data of different

\begin{tabular}{|l|l|l|l|l|l|l|}
\hline Sample & Loc 1 & Loc 2 & Loc3 & Loc 4 & Loc 5 & Loc 6 \\
\hline Loc 1 & 1.000 & & & & & \\
\hline Loc 2 & 0.287 & 1.000 & & & & \\
\hline Loc 3 & 0.498 & 0.517 & 1.000 & & & \\
\hline Loc 4 & 0.287 & 0.900 & 0.517 & 1.000 & & \\
\hline Loc 5 & 0.237 & 0.839 & 0.434 & 0.896 & 1.000 & \\
\hline Loc 6 & 0.085 & 0.800 & 0.587 & 0.797 & 0.693 & 1.000 \\
\hline
\end{tabular}

Nei's Similarity Coefficient generated by UPGMA analysis 


\section{Acknowledgement}

The first author wishes to thank Dr. Mrs. Grace George, Chair Person and the Management of Alpha Arts and Science College for their encouragement.

\section{References}

1. Alam MA, Pallavi Gulati, Aswini KG, Gyan PM and Pradeep KN (2009) Assessment of genetic diversity among Podophyllum hexandrum genotypes of northwestern Himalayan region for Podophyllotoxin production. Indian J. Biotechology. 8, 391-399.

2. Becerra Velasques VB and Gepts P (1994) RFLP diversity in common bean (Phaseolus vulgaris L.). Genome 37, 256-263.

3. Chrubasik S, Pittler $M$ and Roufogalis BD (2005) Zingiberis hizoma: a comprehensive review on the ginger effect and efficacy profiles. Phytomedicine. 12, 684-701.

4. Comes HP and Kadereit JW (1998) The effect of quaternary climatic changes on plant distribution and evolution. Trends Plant Sci. 3. (11), 432-438.

5. Doyle JJ and Doyle JJ (1990) Isolation of plant DNA from fresh tissue. Focus. 12, 13-15.

6. Hebbar SS, Harsha VH and Shripathi GR (2004) Hegde ethnomedicine of Dharwad district in Karnataka, Indiaplants used in oral health care. J. Ethnopharmacol. 94, 261-266.

7. Hedrick PW (2001) Conservation genetics: where are we now? Trends Ecol. Evoult.16, 629-636.

8. Heun M, Murphy JP and Phillips TD (1994) A comparison of RAPD and isozyme analysis for determining the genetic relationships among Avena sterlis L. accessions. Theor. Appl. Genet. 87, 689-696.

9. Ignacimuthu $S$, Ayyanar $M$ and Sankarasivaraman $K$ (2008) Ethnobotanical study of medicinal plants used by Paliyar tribals in Theni district of Tamil Nadu, India. Fitoterapia. 79(8), 562-568.

10. Ismail TS, Gopalakrishnan S, Begum VH and Elango V (1997) Anti-inflammatory activity of Salacia oblonga Wall. and Azima tetracantha Lam. J. Ethnopharmacol. 56(2), 145-152.

11. Jain A, Bhatia S, Banga SS, Prakash CS and Lakshmi Kumaran (1994) Potential use of random amplified polymorphic DNA (RAPD) technique to study the genetic diversity in Indian mustard (Brassica juncea) and its relationship to heterosis. Theor. Appl. Genet. 88, 116122.

12. Jaswanth A, Begum VH, Akilandeswari S, Begum TN, Manimaran S and Ruckmani K (2001) Effects of Azima tetracantha on dermal wound healing in rats. Hamdard Medicus. 44(3), 13-16.

13. Jin-Ming Chen, Fan Liu, Qing- Feng Wang and Timothy J Motley (2008) Phylogeography of a marsh herb Sagittaria trifolia (Alismataceae) in China inferred from cpDNA atpB-rbcL intergenic spacers. Mol. Phylogenetics \& Evol. 48, 168-175.

14. Kirtikar KR and Basu BD (1984) Indian medicinal plants. Vol.1 \& 2. $2^{\text {nd }}$ Ed. Bishennd Singh and Mahendra Pal Singh(eds.), Dehra Dun, 54, 582-584.
15. Mehetre SS, Gomes M and Eapen S (2004) RAPD analysis of hybrid nature of the offspring of Gossypium hirsutum x G. raimondii. Curr. Sci. 84, 24-28.

16. Mohamed $A F$, Wurster $M$, Schröder $G$ and Lindequist $U$ (2007). Antioxidant, antimicrobial and cytotoxic activities of selected medicinal plants from Yemen. $J$. Ethnopharmacol. 111(3), 657-666.

17. Nandgude TD, Bhojwani AP, and Krishna Kinage (2007). Analgesic activity of various extracts of Azima tetracantha (Lam). I. J. Green Pharmacy. 1(1) 37-38.

18. Nei M and Li WH (1979) Mathematical model for studying genetic variation in terms of restriction endonucleases. Proc. of the Natl. Acad. of Sci. USA. 76, 5269-5273.

19. Rodriguez JM, Berke T, Engle L and Nienhuis J (1999). Variation among and within Capsicum species revealed by RAPD markers. Theor. Appl. Genet. 99, 147-156.

20. Sarwat M, Das ES and Srivastava EPS (2008) Analysis of genetic diversity through AFLP, SAMPL, ISSR and RAPD markers in Tribulus terrestris, a medicinal herb. Plant Cell Rep. 27, 519-528.

21. Sayed M. Zain Hasan, Mohammed Shafie B. Shafie and Ramisah M. Shah (2009) Analysis of random amplified polymorphic DNA (RAPD) of Artemisia capillaries (Worm wood capillary) in east coast of Penisular Malaysia. World Appl.Sci. J. 6(7), 976-986.

22. Schaal BA, Hayworth DA, Olsen KM, Rauscher JT and Smith WA (1998) Phylogeographic studies in plants: problems and prospects. Mol. Ecol. 7, 465-474.

23. Slatkin M (1987) Gene flow and the geographic structure of populations. Science. 236, 787-792.

24. Sumer Aras, Ahmet Duran and Gulay Yenilmez (2003). Isolation of DNA for RAPD Analysis from Dry Leaf Material of Some Hesperis L. Specimens. Plant Mol. Biol. Reporter. 21, 461a-461f.

25. Torre A, Lopez S, Yglesias E and Cornelius JP (2008) Genetic (AFLP) diversity of nine Cedrela odorata populations in Madre de Dios, southern Peruvian Amazon. Forest Ecol. Manag. 255, 334-339.

26. Wang X.P, Zou Y.P, and Zhang D.M (1996) Problems in the use of RAPD to the study of genetic diversity and systematis. Acta Botanica Sinica. 38(12), 954-962.

27. Wang W, Chen L, Yang P, Hou L, He C, Gu Z and Liu Z (2007) Assessing genetic diversity of populations of top mouth culter (Culter alburnus) in China using AFLP markers. Biochem. Syst. Ecol. 35, 662-669.

28. Williams JGK, Kubelik AR, Livak KJ, Rafalski JA and Tingey SV (1990) DNA polymorphisms amplified by arbitrary primers are useful as genetic markers. Nucl. Acids Res. 18, 6531-6535.

29. Xie JT, Mchendale S and Yuan CS (2005) Ginseng and diabetes. Am. J. Chin. Med. 33, 397-404

30. Xu H, Lawson D, Kras A and Ryan D (2005) The use of preventive strategies for bone loss. Am. J. Chin. Med. 33, 299-306.

31. Yoo JH, Lee EJ, Kwak CK, Sohn EH, Koh BH, Song IB and Lee KS (2005) Clinical trial of herbal formula on weight loss in obese Korean children. Am. J. Chin. Med. 33, 713-722.
Research article

CIndian Society for Education and Environment (iSee)
"Azima tetracantha: RAPD analysis" http://www.indjst.org
Thendral Hepsibha et al. Indian J.Sci.Technol. 